\title{
Pengetahuan dan Sikap Warga Sekolah Tentang Penanganan Pertama Cedera Siswa di SDN Blunyahrejo Yogyakarta
}

\section{Knowledge and Attitudes of School Members About The Fisrt Aid of Student Injuries at SDN Blunyahrejo Yogyakarta}

\author{
Armenia Diah Sari ${ }^{1}{ }^{*}$, Vita Purnamasari ${ }^{2}$ \\ 1,2 Universitas 'Aisyiyah Yogyakarta Jalan Siliwangi No.63 Nogotirto Gamping Sleman Daerah Istimewa \\ Yogyakarta 55292, Indonesia \\ 1armeniadiahsari@unisayogya.ac.id*; ${ }^{2}$ vita.purnamasari@unisayogya.ac.id \\ * corresponding author \\ Tanggal Submisi: 2 Desember 2020 , Tanggal Penerimaan: 1 Maret 2021
}

\begin{abstract}
Abstrak
Cedera pada anak usia sekolah dapat dicegah jika semua warga sekolah baik siswa, guru dan staf lainnya memahami penanganan pertama cedera anak. Penelitian ini menggambarkan pengetahuan dan sikap warga sekolah tentang penanganan pertama cedera pada anak di SDN Blunyahrejo Yogyakarta. Penelitian survey deskriptif dengan desain cross-sectional. Jumlah sampel yaitu 69 siswa, 13 guru dan staf. Pengumpulan data menggunakan kuesioner. Hasil analisis yaitu pengetahuan siswa tentang penanganan cedera dengan kategori cukup baik $(62,3 \%)$, sikap siswa dengan kategori sangat baik $(52,2 \%)$ dan pengetahuan guru dan staf dengan kategori baik (61,5\%), sikap guru dan staf dengan kategori baik $(53,8 \%)$.
\end{abstract}

Kata kunci : first aid; siswa; guru; cedera

\begin{abstract}
Injury in school-age children can be prevented if all school members, including students, teachers and other staff understand the first aid of injuries. This study describes the knowledge and attitudes of school members about the first aid of injuries to children at SDN Blunyahrejo Yogyakarta. Descriptive survey research with cross-sectional design. The number of samples is 69 students, 13 teachers and staff. Data collection using a questionnaire. The results of the analysis were students' knowledge of injury aid in the fairly good category (62.3\%), the student's attitude in the very good category (52.2\%). Knowledge of teachers and staff in the good category (61.5\%), the attitudes of teachers and staff in the good category (53.8\%).
\end{abstract}

Keywords: first aid; students; teacher; injury

\section{PENDAHULUAN}

Cedera adalah akibat dari faktor internal maupun eksterbal yang dapat menimbulkan gangguan atau kerusakan pada fisik maupun mental (Hastuti 2017) Prevalensi cedera yang dapat mengganggu kegiatan sehari-hari di Indonesia sebesar 9,2\%. Prevalensi cedera setiap tahunnya mengalami peningkatan dilihat dari tahun 2007 sebesar 7,5\% dan tahun 2013 sebesar $8,2 \%$. Prevalensi jenis cedera yang banyak yaitu lecet, lebab dan memar. Prevalensi cedera di Daerah Istimewa Yogyakarta sebesar 10,6\% (Riskesdas 2018).

Cedera dapat terjadi pada siapa saja termasuk pada anak-anak, hal ini dikarenakan anak mememiliki rasa ingin tahu yang besar tetapi belum memiliki pemahaman yang cukup. Banyak faktor yang menyebabkan anak cedera yaitu kurangnya pengawasan, kebebasan untuk melakukan aktivitas, kecanggungan, kelambanan yang disebabkan karena kurangnya 
koordinasi otot gerak, anak yang terlalu aktif dan kurangnya pengendalian emosi (Hermien Nugraheni, Sofwan Indarjo 2018). Cedera pada anak dapat berupa cedera yang disengaja seperti kekerasan yang menggunakan kekuatan fisik, ancaman pada diri sendiri, oranglain, lingkungan masyarakat, penganiayaan anak, pelecehan seksual dan bullying yang dapat mengakibatkan cedera bahkan sampai kematian, gangguan perkebangan serta cedera yang tidak disengaja seperti kecelakaan lalu lintas, tenggelam, keracunan, terbakar dan jatuh (Padrizal Lubis, Oswati Hasanah 2015). Anak usia sekolah rentan terjadi cedera dikarenakan pada masa ini anak dalam aktivitas fisi dan interaksi terhadap lingkungan yang tinggi. Hasil Riset Kesehatan Dasar Tahun 2018 menunjukkan prosentasu proporsi cdera berdasarkan kelompok usia peringkat ke-2 terbanyak terjadi pada anak dengan rentang usia 5-14 tahun (Riskesdas 2018). Berdasarkan tempat kejadian, sekolah merupakan salah satu tempat yang paling sering terjadi cedera pada anak selain lingkungan rumah. Tempat di sekolah yang berbahaya dan menimbulkan cedera pada anak seperti tempat bermain, tempat olahraga, dan koridor sekolah (Hermien Nugraheni, Sofwan Indarjo 2018). Faktor yang dapat menimbulkan cedera anak disekolah seperti kemampuan anak sendiri, sarana prasarana yang digunakan disekolah, fasilitas, lingkungan dan lain-lain (Haryanto 2017).

Cedera pada anak dapat berakibat fatal karena anak masih dalam tahap pertumbuhan dan perkembangan. Cedera pada anak usia sekolah dapat menimbulkan kecacatan baik sementara maupun permanan yang dapat mengganggu pertumbuhan dan perkembangan anak. Cedera bukan hanya berdampak pada fisi tetapi juga berdampak pada mental anak seperti trauma, Post Traumatic Syndrome Disorder (PTSD), phobia dan cemas (Padrizal Lubis, Oswati Hasanah 2015). Cedera pada anak usia sekolah (siswa) dapat dicegah apabila siswa, guru serta warga sekolah memahami tentan penanganan pertama cedera yang bermanfaat untuk meminimalkan cedera, menciptakan lingkungan sekolah dan belajar yang aman, mengantisipasi faktor yang dapat meimbulkan cedera serta siswa mengetahui sumber dan penanganan cedera. Informasi terkait cedera dan bagaimanan penanganannya belum semua warga disekolah dapatkan sehingga diperlukan pengkajian sejauh mana pengetahuan dan sikap warga sekolah terhadap penanganan pertama cedera disekolah.

Studi pendahuluan yang dilakukan di SDN Blunyahrejo ditemukan bahwa dalam lingkung sekolah kadang terjadi cedera pada siswa saat istirahat (siswa bermain) atau saat berolahraga. Guru dan warga sekolah yang lain belum mengetahui secara benar tentang penanganan pertama pada siswa yang mengalami cedera, sehingga guru atau petugas sekolah lainnya sering membawa siswa yang mengalami cedera langsung ke pelayanan kesehatan seperti puskesmas tanpa memberikan penanganan pertama dahulu, serta disekolah juga terdapat ruang UKS yang belum secara optimal digunakan. Tujuan penelitian ini adalah mengetahui gambaran pengetahuan dan sikap warga sekolah tentang penanganan pertama cedera pada anak di SDN Blunyahrejo Yogyakarta.

\section{METODE PENELITIAN}

Penelitian ini menggunakan metode survey deskriptif, pendekatan kuantitatif dengan desain cross-sectional. Penelitian ini dilaksanakan pada bulan Agustus - September 2020 di SDN Blunyahrejo Yogyakarta. Populasi pada penelitian ini yaitu semua siswa kelas 4,5 dan 6 serta guru dan staf di SDN Blunyahrejo Yogyakarta.

Teknik pengumpulan data dalam penelitian ini yaitu non probability sampling dengan teknik purposive sampling yaitu teknik pengambilan sampel dengan sumber data berdasarkan pertimbangan tertentu (Sugiyono 2016). Kriteria inklusi yaitu siswa kelas 4,5,6, guru dan staf disekolah yang bersedia menjadi responden, Kriteria ekslusi yaitu responden yang tidak datang mengambil kuesioner ke sekolah. Jumlah sampel dalam penelitian ini adalah siswa berjumlah 69 responden dan guru dan staf berjumlah 13 responden. Variabel yang diteliti dalam penelitian ini adalah pengetahuan dan sikap. 
Pengumpulan data penelitian didapatkan dari pengisian kuesioner pengetahuan dan sikap warga sekolah yang dimodifikasi dan telah dilakukan uji konstruksi/uji pakar (Haryanto 2017),(Zakiya 2018), (Ernawati 2018). Data penelitian dilakukan uji analisis data menggunakan program komputer dengan analisis deskriptif yang disajikan dalam bentuk frekuensi dan persentase. Penelitian ini mendapatkan surat persetujuan layak etik dari Komite Etik Penelitian Kesehatan Universitas 'Aisyiyah Yogyakarta No. 1315/KEP-UNISA/V/2020.

\section{HASIL DAN PEMBAHASAN}

Penelitian ini bertujuan mengetahui gambaran seberapa baik pengatahuan warga sekolah tentang penanganan pertama cedera pada siswa di SDN Blunyarejo Yogyakarta. Data dalam penelitian ini diperoleh dari pengumpulan kuesioner dengan analisis deskriptif yang ditunjukkan menggunakan persentase.

Tabel 1. Distribusi Berdasarkan Karakteristik Responden (Siswa) 2020 ( $\mathrm{n}=69)$

\begin{tabular}{lccc}
\hline & Variabel & Frekuensi & Persentase (\%) \\
\hline Klasifikasi Usia & & 2.9 \\
\hline 9 tahun & 29 & 42 \\
\hline 10 tahun & 22 & 31.9 \\
\hline 11 tahun & 11 & 15.9 \\
\hline 13 tahun & 5 & 7.2 \\
\hline Jenis Kelamin & & 46.4 \\
\hline Laki-laki & 32 & 53.6 \\
\hline Perempuan & 37 & \\
\hline
\end{tabular}

Hasil penelitian pada tabel 1 yang menunjukkan distribusi karakteristik responden siswa. Distribusi karakteristik responden (siswa) didapatkan bahwa sebagian besar responden adalah berusia 10 tahun sebanyak 29 responden (42\%) dan berusia 11 tahun sebanyak 22 responden $(31,9 \%)$. Karakterisitik responden siswa berdasarkan jenis kelamin didapatkan data responden yang berjenis kelamin perempuan berjumla 37 responden $(53,6 \%)$ dan lakilaki berjumlah 32 responden $(46,4 \%)$.

Tabel 2. Distribusi Berdasarkan Karakteristik Responden (Guru dan Staf) 2020 (n=13)

\begin{tabular}{lcc}
\hline \multicolumn{1}{c}{ Variabel } & Frekuensi & Persentase (\%) \\
\hline Klasifikasi Usia & 2 & 15.4 \\
\hline Remaja Akhir (17 - 25 tahun) & 1 & 7.7 \\
\hline Dewasa Awal (26-35 tahun) & 2 & 15.4 \\
\hline Dewasa Akhir (36-45 tahun) & 4 & 30.8 \\
\hline Lansia Awal (46-55 tahun) & 4 & 30.8 \\
\hline Lansia Akhir (56 -65 tahun) & & \\
\hline Jenis Kelamin & 4 & 30.8 \\
\hline Laki-laki & 9 & 69.2 \\
\hline Perempuan & 4 & \\
\hline
\end{tabular}




\section{Pendidikan Terakhir}

\begin{tabular}{lcc}
\hline Diploma 3/D3 & 1 & 7.7 \\
\hline Sarjana/S1 & 12 & 92.3 \\
\hline $\begin{array}{l}\text { Pengalaman Pelatihan Penanganan Pertama } \\
\text { Cedera }\end{array}$ & & \\
\hline Pernah & 1 & 7.7 \\
\hline Tidak Pernah & 12 & 92.3 \\
\hline
\end{tabular}

Distribusi karakteristik responden (guru dan staf) berdasarkan tabel 2 didapatkan bahwa sebagian besar responden guru dan staf yang berusia dengan klasifikasi lansia awal (46-55 tahun) dan lansia akhir (56-65 tahun) masing-masing sebanyak 4 responden (30,8\%). Karakteristik responden guru dan staf berdasarkan jenis kelamin didapatkan data responden dengan berjenis kelamin perempuan sebanyak 9 responden $(69,2 \%)$. Karakteristik responden guru dan staf berdasarkan Pendidikan didapatkan Pendidikan terakhir Sarjana (S1) sebanyak 12 responden $(92,3 \%)$. Karakteristik responden guru dan staf berdasarkan pengalaman pelatihan penanganan pertama cedera didapatkan hasil sebanyak 12 responden $(92,3 \%)$ belum pernah mendapatkan pelatihan.

Cedera merupakan kondisi yang diakibatkan oleh kerusakan fisik yang terjadi ketika tubuh mengalami penurunan energi dalam jumlah yang melebihi ambang batas toleransi fisiologi atau akibat dari kurangnya satu atau lebih elemen penting seperti oksigen (Sminkey 2008) atau cedera adalah akibat factor internal maupun eksternal yang menimbulkan gangguan atau kerusakaan pada fisik maupun mental (Hastuti 2017).

\section{Pengetahuan Warga Sekolah Tentang Penanganan Pertama Cedera}

Tabel 3. Distribusi Pengetahuan Siswa ( $\mathrm{n}=69$ ), Guru dan Staf $(\mathrm{n}=13)$ Tentang Penanganan Pertama Cedera

\begin{tabular}{l|c|c}
\multicolumn{1}{c}{ Tingkat Pengetahuan } & Frekuensi (n) & Persentase (\%) \\
\hline Siswa & & \\
Baik & 24 & 34.8 \\
Cukup baik & 43 & 62.3 \\
Kurang baik & 2 & 2.9 \\
\hline Guru dan Staf & & \\
Baik & 1 & 7.7 \\
Cukup baik & 8 & 61.5 \\
Kurang baik & 4 & 30.8
\end{tabular}

Hasil penelitian yang ditunjukkan dalam tabel 3 didapatkan bahwa pengetahuan siswa tentang penanganan pertama cedera sebanyak 43 responden siswa $(62,3 \%)$ dengan kategori cukup baik dan sebanyak 24 responden siswa $(34,8 \%)$ dengan kategori baik. Hal ini sejalan dengan hasil penelitian yang dilakukan oleh Haryanto (2017) bahwa pengetahuan siswa tentang cedera, pencegahan dan perawatan cedera dalam katogori sedang sebesar 51,2\% (Haryanto 2017). Hal ini sejalan dengan penelitian yang dilakukan oleh Yuliana dkk (2020) bahwa sebagian besar anak memiliki pengetahuan yang cukup terkait dengan resiko terjadinya cedera di SDN 1 Beureno Bojonegoro (Yuliana, Farida Juanita 2019). 
Pengetahuan tentang penanganan pertama cedera siswa di SDN Blunyahrejo didasarkan pada 3 variabel yaitu pengetahuan cedera, pengetahuan pencegahan cedera dan pengetahuan perawatan dan penanganan cedera, sedangkan 5 indikator yaitu terdiri dari pengertian cedera, bagian tubuh yang sering cedera, tingkat klasifikasi cedera, pendegahan cedera, perawatan dan penanganan cedera. Menurut Notoadmojo (2014) dalam Afnis (2018) bahwa pengetahuan merupakan hasil dari penginderaan manusia atau hasil tahu individu terhadap suatu objek melalui pancaindera yang dimiliki individu tersebut. Pengetahuan memiliki tingkatan, yang mana tingkat pengetahuan setiap orang berbeda-beda. Hal ini dipengaruhi oleh beberapa faktor yaitu pengalaman, tingkat pendidikan, sumber informasi, usia, lingkyngan dan sosial budaya (Tirtawidi 2018).

Hasil penelitian berdasarkan dari usia didapatkan bahwa sebagian besar anak berusia 10 tahun sebanyak 29 responden (42\%) dimana pada usia ini anak berada pada usia sekolah dasar. Usia sekolah dasar merupakan dimana anak telah memasuki masa sekolah yang mana menurut teori kognitif (Piaget) bahwa naka masuk dalam operasional kongkret (concrete operational) pada usia 7-11 tahun. Tahapan operasional konkrit merupakan kondisi anak telah mengfungsikan akalnya untuk berfikir secara logis terhadap sesuatu yang nyata, yang mana pada tahap ini anak memiliki pemahaman lebih baik dari anak pada tahap praoperasional (Bujuri 2018).

Berdasarkan tabel 3 didapatkan pengetahuan guru dan staf tentang penanganan pertama cedera sebanyak 8 responden $(61,5 \%)$ dengan kategori cukup baik. Guru merupakan penolong pertama ketika siswa mengalami suatu kejadian disekolah serta guru juga sebagai orangtua siswa disekolah yang menjadi pelindung siswa. Guru sekolah dasar memiliki peran penting dalam merawat anak sekolah dari dengan pengawasan dan pencegahan bahaya bagi kesehatan anak, dan guru harus dilatih dengan baik tentang pertologan pertama untuk menyelamatkan anak-anak (Younis and El-Abassy 2015). Oleh karena itu, guru harus memiliki keterampilan dasar dalam penanganan pertama cedera disekolah untuk meminimalkan dampak atau efek dari cedera yang dialami siswa. Hal ini didukung dengan penelitian yang dilakukan oleh Zakiya (2018) bahwa adanya hubungan tingkat pengetahuan guru dengan perilaku pertolongan pertama pada cedera (Zakiya 2018).

Pengetahuan guru yang kurang tepat mengenai penanganan pertama akan mempengaruhi pelaksanaan pertolongan pertama pada siswa yang sesuai yang mana akan meningkatkan komplikasi dari cedera yang dialami siswa dilingkungan sekolah. Pelatihan pertolongan pertama pada guru akan meningkatkan keselamatan bagi semua warga dilingkungan sekolah (Adib-Hajbaghery and Kamrava 2019).

Pengetahuan seseorang dipengaruhi oleh beberapa faktor antara lain usia, pendidikan, pengalaman, media, dan budaya. Pengetahuan guru dan anak sekolah berada pada rentang cukup baik, hal ini dapat dipengaruhi oleh faktor pengalaman. Guru yang mempunyai pengalaman lebih akan mempunyai pengetahuan terhadap penanganan cedera yang baik pula, selain itu faktor usia juga menjadi salah satu faktor yang mempengaruhi pengetahuan (Baharudin 2020).

Pengetahuan yang dimiliki oleh siswa juga dipengaruhi oleh beberapa faktor diantaranya adalah faktor lingkungan sekitar. Pemahaman anak dapat dibentuk dari lingkungan sosial sekitarnya, serta orang tua dan sekolah, sehingga sekolah dapat memberikan tambahan pengetahuan terhadap siswanya tentang penanganan cedera pada anak melalui berbagai pelatihan (Baharudin 2020).

\section{Sikap Warga SekolahTentang Penanganan Pertama Cedera}


Tabel 4 Distribusi Sikap Siswa ( $n=69)$, Guru dan Staf $(n=13)$ Tentang Penanganan Pertama Cedera 2020

\begin{tabular}{|l|c|c|}
\hline \multicolumn{1}{|c|}{ Sikap } & Frekuensi (n) & Persentase (\%) \\
\hline Siswa & 36 & 52.2 \\
\hline Sangat Baik & 32 & 46.4 \\
\hline Baik & 1 & 1.4 \\
\hline Cukup baik & 0 & 0 \\
\hline Kurang baik & \multicolumn{2}{|l|}{} \\
\hline Guru dan Staf & 6 & 46.2 \\
\hline Sangat Baik & 7 & 53.8 \\
\hline Baik & 0 & 0 \\
\hline Cukup baik & 0 & 0 \\
\hline Kurang baik & &
\end{tabular}

Pertolongan pertama merupakan perawatan untuk setiap cedera atau penyakit yang mendadak sebelum profesional medis memberikan bantuan, dimana anak-anak menghabiskan sebagian waktunya disekolah dibawah pengawasan langsung guru (Sharma, Kumar, and Masih 2014). Pengetahuan dan sikap sebagai salah satu faktor yang merupakan penentu bagaimana individu berperilaku, oleh karena itu pengetahuan dan sikap warga sekolah tentang penanganan pertama cedera siswa disekolah penting dalam meminimalkan dampak dari cedera seperti kecacatan atau kematian.

Anak usia sekolah dasar sering mengalami cedera ringan seperti keseleo, luka bakar ringan, epistaksis dan sebagainya, dalam kondisi ini anak membutuhkan penanganan pertama dalam mencegah dampak dari cedera tersebut menjadi lebih buruk, dan ini merupakan peran guru sekolah yang terdekat untuk dapat memberikan penanganan pertama anak dengan cedera ringan. Ketika guru dan staf sekolah memiliki pengetahuan dan sikap yang cukup mengenai bagaimanan penanganan pertama cedera, hal ini dapat meminimalkan terjadinya komplikasi bahkan menyelamatkan nyawa anak. Hal ini didukung dengan penelitian yang dilakukan oleh Sharma, dkk 2014 bahwa program pelatihan dapat meningkatkan pengetahuan dan praktik guru dalam manajemen penanganan pertama anak disekolah terkait dengan luka ringan (Sharma et al. 2014)

Sikap merupakan suatu reaksi terhadap sesuatu perasaan, pemikiran dan tindakan yang dipelajari untuk merespon sesuatu secara konsisten terhadap suatu objek tertentu (Kusmaningtias 2017). Dalam penelitian ini yang dimaksud adalah tentang penanganan pertama cedera. Berdasarkan tabel 4 dalam penelitian ini dapatkan bahwa sikap siswa dalam penanganan pertama cedera 52,2 \% dalam kategori sangat baik. Hal ini berkaitan dengan pengetahuan siswa terhadap penanganan pertama cedera telah cukup baik. Hal ini juga didukung dari Wawan \& Dewi, 2016 dalam Herlianita dkk, 2020 bahwa sikap dipengaruhi pengalaman dan emosi yang bersangkutan seperti setuju-tidak setuju untuk sikap harus sejalan dengan pengetahuan yang diperoleh dari Pendidikan kesehatan sehingga menimbulkan sikap yang baik (positif) (Herlianita et al. 2020).

Sikap pada guru dan staf pada penelitian ini didapatkan sikap guru dan staf dalam penanganan pertama cedera pada siswa sebesar 53,8\% dalam kategori baik. Hal ini dapat dilihat dari tabel 2 bahwa guru dan staf di SDN Blunyahrejo Yogyakarta mayoritas guru dan staf dengan tingkat pendidikan Strata Satu, walaupun mayoritas guru belum pernah mengikuti pelatihan penanganan pertama cedera, tetapi dari tingkat pengetahuan dan sikap guru dan staf terhadap penanganan pertama cedera pada siswa sudah cukup baik.

Sikap merupakan suatu reaksi atau respon tertututp dari seseorang pada stimulus atau obyek tertentu. Sikap belum dapat dikatakan sebagai suatu tindakan, tetapi merupakan 
predisposisi dari tindakan (Notoadmodjo 2014). Sikap mempunyai tiga komponen yaitu komponen kognitif, komponen afektif dan komponen konatif. Pada penelitian ini menunjukkan bahwa sikap guru dan siswa terhadap penanganan cedera mayoritas dalam kategori baik dan sangat baik, hal ini dipengaruhi oleh komponen sikap salah satunya adalah kognitif yaitu pendapat atau pengetahuan sesorang terhadap stimulus tertentu, sehingga dapat disimpulkan bahwa terdapat kaitan antara pengetahuan dan sikap terhadap penanganan cedera anak.

Sikap berkaitan dengan pengetahuan dan pemikiran seseorang dimana jika pengetahuan mengenai penanganan pertama oleh warga sekolah akan membuat siswa, guru dan staf untuk berfikir dan berusaha agar anak selalu terjaga keselamatannya disekolah, ketika individu tersebut berfiki maka komponen emosi serta keyakinan akan terbawa sehingga akan meningkatkan kemampuan dan keinginan untuk melakukan tindangan penanganan pertama segera untuk mencegah dan meminimalkan kecacatan bahkan kematian ketika siswa mengalami cedera disekolah (Rahmanida 2016).

\section{SIMPULAN}

Penelitian deksripsi pengetahuan dan sikap warga sekolah tentang penanganan pertama cedera pada siswa di SDN Blunyahrejo Yogyakarta didapatkan hasil menunjukkan bahwa karakteristik usia siswa mayoritas usia 10 tahun (42\%), jenis kelamin sebagian besar perempuan $(53,6 \%)$, siswa memiliki pengetahuan cukup baik $(62,3 \%)$ dan sikap sangat baik $(52,2 \%)$ tentang penanganan pertama cedera pada siswa. Sedangkan karakteristik usia guru dan staf sekolah mayoritas kalsisifikasi usia lansia awal dan akhir 30,8\%, mayoritas berjenis kelamin perempuan 69,2\%, tingkat Pendidikan mayoritas strata satu (S1) 92,3\% dan mayoritas tidak pernah mengikuti pelatihan penanganan pertama cedera 92,3\%, tingkat pengetahuan guru dan staf cukup baik $(61,5 \%)$ dan sikap baik $(53,8 \%)$.

\section{SARAN}

Bagi Ilmu Keperawatan diharapkan penelitian ini dapat menjadi sumber pembelajaran dan informasi mengenai cedera pada anak, sehingga perawat dapat memberikan Pendidikan kesehatan atau pelatihan terkait dengan upaya pencegahan dan penanganan cedera pada anak. Bagi Kepala Sekolah SDN Blunyahrejo penelitian ini dapat menjadi salah satu sumber informasi data pengetahuan dan sikap warga sekolah tentang penanganan pertama cedera pada siswa disekolah sebagai dasar untuk membuat Standar Operasional Prosedur atau kebijakan-kebijakan dalam upaya pencegahan dan penanganan cedera pada siswa serta dalam menyusun beberapa program untuk keamanan siswa disekolah. Bagi peneliti selanjutnya diharapkan dapat melakukan penelitian yang terkait dengan pencegahan dan penanganan cedera dengan metode dan desain penelitian lain serta pada tingkatan kelompok usia anak lainnya

\section{REFERENCE}

Adib-Hajbaghery, Mohsen, and Z. Kamrava. (2019). Iranian Teachers' Knowledge about First Aid in the School Environment. Chinese Journal of Traumatology - English Edition 22(4):240-45. doi: 10.1016/j.cjtee.2019.02.003.

Baharudin, Sri Anggraini. (2020). Pelatihan Child Safety Dalam Pencegahan Dan Penanganan Kecelakaan Pada Anak TK Aisyiyah Mamajang Makasar. Jurnal Aplikasi Ipteks (Bhakti Persada) 6(1):01-08.

Bujuri, Dian Andesta. (2018). Analisis Perkembangan Kognitif Anak Usia Dasar Dan Implikasinya Dalam Kegiatan Belajar Mengajar. LITERASI (Jurnal Ilmu Pendidikan) 9(1):37. doi: 10.21927/literasi.2018.9(1).37-50.

Ernawati, Wayan. (2018). Tingkat Pengetahuan Siswa Kelas 5 Tentang Cederaolahraga, 
Pencegahan Dan Perawatan Cedera Di Sd Negeri Beji Kecamatan Wates, Kabupaten Kulon Progo.

Haryanto, Debi Dwi. (2017). Pengetahuan Tentang Cedera, Pencegahan Dan Perawatan Cedera Siswa Kelas Atas Sd N 2 Bugisan Prambanan Klaten Tahun 2016. Journal of Chemical Information and Modeling 110(9):1689-99.

Hastuti, Dwi. (2017). Hubungan Pengetahuan Tentang Antisipasi Cedera Dengan Praktik Pencegahan Cedera Pada Anak Usia Toddler Di Rw 01 Kelurahan Manggahang Wilayah Puskesmas Jelekong Kabupaten Bandung. Jurnal Keperawatan Komprehensif 3(1):52. doi: 10.33755/jkk.v3i1.85.

Herlianita, Risa, Chairul Huda Al Husna, Faqih Ruhyanudin, Indri Wahyuningsih, Zaqqi Ubaidillah, Ahmad Try Theovany, and Yunika Era Pratiwi. (2020). Pengatuh Pendidikan Kesehatan Terhadap Sikap Dan Praktik Pada Pertolongan Pertama Penanganan Luka Bakar. Holistik Jurnal Kesehatan 14(2):163-69.

Hermien Nugraheni, Sofwan Indarjo, dan Suhat. (2018). Buku Ajar Promosi Kesehatan Berbasis Sekolah. Yogyakarta: Deepublish.

Kusmaningtias, Luluk. (2017). Sikap Siswa Kelas Atas Terhadap Pembelajaran Pendidikan Jasmani Di SD Negeri 3 Penga.

Notoadmodjo, Soekidjo. (2014). Ilmu Perilaku Kesehatan. Jakarta: Rineka Cipta.

Padrizal Lubis, Oswati Hasanah, Ari Pristiani Dewi. (2015). Gambaran Tingkat Risiko Cedera Pada Anak Usia Sekolah. JOM 2(2):1335-44.

Rahmanida, Nindya. (2016). Pengetahuan Dan Sikap Guru Tentang Pertolongan Pertama Pada Kegawatdaruratan Di Sekolah Dasar Wilayah Jatinnagor. Universitas Padjajaran.

Riskesdas. (2018). Salam Sehat! Semoga Fakta Yang Disajikan Dalam Buku Ini, Bermanfaat Untuk Perbaikan Perencanaan Pembangunan Kesehatan. Laporan Riskesdas Nasional 2018120.

Sharma, RajeshKumar, Atul Kumar, and Shobha Masih. (2014). Knowledge and Practice of Primary School Teachers about First Aid Management of Selected Minor Injuries among Children. International Journal of Medicine and Public Health 4(4):458. doi: 10.4103/2230-8598.144114.

Sminkey, L. (2008). World Report on Child Injury Prevention. Injury Prevention 14(1):69. doi: 10.1136/ip.2007.018143.

Sugiyono. (2016). Metode Penelitian Kuantitatif, Kualitatif Dan Kombinasi (Mixed Methods). Bandung: Alfabeta.

Tirtawidi, Afnis. (2018). Hubungan Tingkat Pengetahuan Masyarakat Dengan Perilaku Masyarakat Dalam Manajemen Stres Di Dukuh Tengah Desa Nambangrejo Kecamatan Sukorejo Kabupaten Ponorogo. Repository Muhammadiyah University of Ponorogo.

Younis, Jaklein R., and Amal El-Abassy. (2015). Primary Teachers' First Aid Management of Children's School Day Accidents: Video-Assisted Teaching Method versus Lecture Method. Journal of Nursing Education and Practice 5(10):60-69. doi: 10.5430/jnep.v5n10p60.

Yuliana, Farida Juanita, Isni Lailatul Maghfiroh. (2019). Pengaruh Pendidikan Kesehatan Terhadap Tingkat Pengetauan Anak Tentang Resiko Terjadinya Cedera Di SDN 1 Baureno Bojonegoro Tahun 2019. Repository Umla.

Zakiya, Toyibatus. (2018). Hubungan Tingkat Pengetahuan Guru Dengan Perilaku Pertolongan Pertama Pada Cedera Di Lingkungan Sekolah Menengah Pertama Di Kota Malang. 